\title{
POLA ASUH KELUARGA PEMULUNG DALAM PEMBENTUKAN PERILAKU SOSIAL ANAK USIA DINI
}

\author{
Habibah Ainul Janah ${ }^{1}$; Nila Fitria ${ }^{1}$ \\ ${ }^{1}$ Program Studi Pendidikan Guru Pendidikan Anak Usia Dini, Fakultas Psikologi dan Pendidikan, \\ Universitas Al Azhar Indonesia, Jalan Sisingamangaraja Kebayoran baru, Jakarta Selatan 12110 \\ Penulis untuk Korespondensi/E-mail:nilafitria@uai.ac.id
}

\begin{abstract}
Abstrak - Pola asuh orangtua bagi pembentukan perilaku sosial anak usia dini di keluarga pemulung seharusnya diperhatikan dengan sangat baik, karena pola asuh merupakan tanggung jawab dari orangtua kepada seorang anak selama menjalankan dan mengasuh anak mereka dalam kehidupan sehari-hari. Selama orangtua dari keluarga pemulung tersebut menjalankan pola asuh kepada anakanak mereka, seharusnya orangtua melakukan sebuah interaksi. Interaksi tersebut digunakan dengan cara seperti: berbicara, bernyanyi, bercerita, dan bermain bersama antara orangtua kepada seorang anak. Interaksi sangat penting dilakukan karena akan berpengaruh kepada masa pertumbuhan dan perkembangan perilaku sosial anak usia dini terhadap lingkungan sosialnya. Penelitian ini bertujuan untuk mengetahui gambaran pola asuh orangtua dalam membentuk perilaku sosial pada seorang anak di lingkungan keluarga pemulung. Dalam penelitian yang menjadi subjek penelitian yaitu merupakan 3 keluarga pemulung yang terdiri dari 3 pasangan orangtua dan 3 orang anak yang berusia 4 sampai 5 tahun. Penelitian ini menggunakan metode penelitian kualitatif, dan menggunakan beberapa tehnik pengumpulan data seperti: observasi, wawancara mendalam, dan dokumentasi. Serta juga menggunakan proses analisa data dengan menggunakan model Miles dan Huberman. Hasil penelitian ini menunjukan bahwa pola asuh yang diterapkan oleh orangtua keluarga pemulung dalam kehidupan sehari-hari yaitu menggunakan pola asuh demokratis dan pola asuh otoriter.
\end{abstract}

Kata Kunci: Pola Asuh, Perilaku Sosial Anak di Keluarga Pemulung

Abstract - Parenting patterns for the formation of social behavior in early childhood scavengers should be considered very well, because parenting is the responsibility of parents to a child while running and caring for their children in everyday life. As long as the parents of the scavenger families practice parenting for their children, parents should do an interaction. The interaction is used in ways such as: talking, singing, telling stories, and playing together between parents to a child. Interaction is very important because it will affect the growth and development of social behavior of young children towards their social environment. This study aims to determine the parenting patterns in shaping social behavior in a child in a scavenger family environment. In the study, the subjects of the study were 3 scavenger families consisting of 3 parents and 3 children aged 4 to 5 years. This study uses qualitative research methods, and uses several data collection techniques such as: observation, in-depth interviews, and documentation. As well as using the data analysis process using the Miles and Huberman models. The results of this study indicate that parenting applied by scavenger family parents in daily life is using democratic parenting and authoritarian parenting.

Keyword: Parenting, Child Social Behavior in Family Scavengers 


\section{PENDAHULUAN}

$\mathrm{O}$ rangtua merupakan orang yang bertanggung jawab terhadap seorang anak sejak usia lahir sampai anak

tersebut dapat tumbuh dan berkembang menjadi pribadi yang dewasa. Orangtua harus dapat memberikan pola asuh yang sesuai dengan perkembangan dan pertumbuhan seorang anak, agar seorang anak dapat menerima pola asuh yang diberikan kepadanya dengan baik serta dapat memotivasi kehidupan seorang anak tersebut (Setiawan dalam Hurlock, 2010).

Pola asuh yang diterapkan oleh orangtua kepada seorang anak yaitu dengan memberikan cinta kasih, perhatian, mendidik seorang anak sesuai dengan perkembangan, serta membentuk perilaku seorang anak agar anak dapat mengerti sebuah aturan yang berlaku di lingkungan tempat tinggal mereka.

\section{Pola Asuh}

Secara epistomologi kata pola dapat diartikan sebagai cara kerja dan kata asuh dapat dikatakan dalam bentuk menjaga, merawat, mendidik, membimbing, mengasuh serta mengarahkan seorang anak. Pola asuh adalah cara terbaik yang ditempuh oleh orangtua dalam mendidik seorang anak sebagai perwujudan dari tanggung jawab kepada seorang anak dalam kehidupan seharihari (Thohah, 2002). Menurut Kohn dalam Thohah (2002), pola asuh merupakan sikap orangtua dalam berhubungan dengan seorang anak, sikap ini dapat terlihat dari berbagai segi antara lain dari cara orangtua memberikan peraturan kepada seorang anak, cara orangtua memberikan perhatian serta hukuman selama menjalankan kehidupan sehari-hari

Terkait dengan pembahasan mengenai pola asuh yang diterapkan oleh orangtua kepada seorang anak, maka menurut Baumrind (2004), terdapat beberapa macam pola asuh antara lain sebagai berikut: (a) pola asuh demokratis, (b) pola asuh otoriter, (c) pola asuh permisive.

\section{Pola Asuh Demokratis}

Pola Asuh Demokratis adalah pola asuh yang memperiortaskan kepentingan seorang anak, akan tetapi tidak ragu-ragu untuk mengikut sertakan seorang anak dalam kehidupan seharihari. Pola asuh demokratis sangatlah bersikap rasional, serta selalu mendasari setiap tindakannya kepada rasio atau pemikiran yang ada (Baumrind, 2004).

Pola Asuh Demokratis akan menghasilkan dampak kepada seorang anak seperti : anak menjadi mandiri, anak dapat mampu berhubungan yang baik dengan temantemannya, anak akan mampu menghadapi sebuah permasalahan dengan baik, dan anak akan mempunyai minat terhadap hal-hal yang baru, serta seorang anak dapat mampu kooperatif terhadap orang lain.

Menurut Mahmud (2003), dalam menerapkan pola asuh demokratis terdapat beberapa ciri, antara lain seperti berikut: (1) dalam pola asuh demokratis orangtua menjadikan dirinya sendiri menjadi panutan bagi seorang anak, (2) dalam pola asuh demokratis orangtua sangat bersikap hangat kepada seorang anak, (3) selalu melibatkan anak dalam setiap kegiatan, (4) selalu menghargai sebuah pendapat dan keinginan seorang anak.

Sikap dan perilaku dari orangtua yang menerapkan pola asuh demokratis yakni orangtua mampu berani menegur seorang anak apabila anak berperilaku buruk dan orangtua dengan pola asuh demokratis dapat mengarahkan perilaku seorang anak sesuai dengan ketentuan yang berlaku, sehingga seorang anak dapat memiliki sikap dan perilaku serta keterampilan yang sangat baik.

\section{Pola Asuh Otoriter}

Pola Asuh Otoriter adalah pola asuh yang membatasi, menghukum, dan sering menuntut seorang anak untuk mengikuti segala perintah dari orangtua dan menghormati pekerjaan atau usaha yang berasal dari orangtuanya tersebut (Baumrind, 2004).

Pola asuh otoriter akan menghasilkan dampak kepada seorang anak, antara lain sebagai berikut : anak menjadi pendiam dan penakut, anak tertutup, seorang anak tidak mempunyai inisiatif serta tidak dapat menentukan sebuah 
pendapat dengan baik, seorang anak sangat mudah cemas akan sesuatu hal yang dilakukan.

Adapun beberapa ciri-ciri seorang anak yang berasal dari orangtua yang menggunakan bentuk pola asuh otoriter, antara lain seperti berikut: (1) seorang anak yang mempunyai orangtua otoriter cenderung mempunyai sifat yang cengeng, (2) seorang anak sering merasakan canggung saat berteman, (3) seorang anak memiliki prestasi belajar yang rendah apabila dibandingkan dengan teman-temannya.

\section{Pola Asuh Permisive}

Pola asuh permisive menurut Baumrind (2004), adalah cara orangtua mengasuh seorang anak dengan cara membiarkan seorang anak berbuat sesuai dengan keinginannya sendiri. Orangtua permisive tidak memberikan arahan, nasihat, atau sebuah teguran kepada seorang anak.

Pola asuh permisive menurut Baumrind terbagi menjadi 2 yaitu: (pola asuh Permisive Neglectfull dan pola asuh Permisive Indulgent). Pola asuh Permisive Neglectfull adalah pola asuh yang tidak memonitor seorang anak dalam kegiatan sehari-hari. Pola asuh ini cenderung mengabaikan tanggung jawab dalam mengasuh dan mendidik seorang anak dalam kehidupan sehari-hari. Sedangkan dasarnya menurut pola asuh Permisive Indulgent adalah pola asuh yang dilakukan oleh orangtua yang masih melibatkan seorang anak dengan aktivitas dalam kehidupan sehari-hari. Pola asuh permisive Indulgent ini sangat memanjakan seorang anak dan mengizinkan seorang melakukan apa yang anak inginkan.

Dari penjelasan mengenai pola asuh permisive ini, maka akan terlihat beberapa dampak kepada seorang anak, antara lain seperti berikut: anak yang agresif, anak yang tidak patuh, anak yang kurang percaya diri, dan menghasilkan anak yang ingin menang sendiri akan sesuatu hal yang dilakukannya tersebut.

Berdasarkan uraian ketiga pola asuh tersebut, maka yang dimaksud dengan pola asuh adalah cara dari sikap atau perilaku orangtua selama berhubungan dan berinteraksi dengan seorang anak, yang didalamnya terdapat cara seperti: merawat, mendidik, serta mengasuh anak dalam menjalankan kehidupan sehari-hari.

\section{Keluarga pemulung}

Keluarga pemulung adalah beberapa orang yang memulung dan mencari nafkah dengan cara memungut, serta memanfatkanbeberapa sampah seperti bungkus rokok, plastic, kertas, kardus bekasdansebagainya, untukmencukupi kebutuhan kehidupan mereka (Lukman, 2000).

Secara konseptual keluarga pemulung adalah lapisan ekonomi dan budaya yangberadapaling bawah dalam strategi masyarakat. Hal tersebut disebabkan karena keluarga pemulung tidak memiliki rumah yang memadai, penghasilan yang cukup, penghasilan mereka sangatlah rendah. Keluarga pemulung sering melakukan beberapa hal yang kurang terpuji dan kurang disukai olehmasyarakat, karena merekasering melakukan kegiatansepertimencuri dalam kehidupan ini (Wardosarjoeno, 2002 ).

Pola asuh menurut Baumrind (2014), terdiri dari 3 macam yaitu: demokratis, permisive, dan otoriter. Dampak dari pola asuh demokratis akan menghasilkan anak yang mandiri, dampak dari pola asuh otoriter akan menghasilkan anak yang pendiam dan penakut, serta dampak dari pola asuh permisive akan menghasilkan akan anak yang manja dan kurang percaya diri dengan lingkungan sosial tempat tinggal mereka.

Masing-masing pola asuh yang diterapkan oleh orangtua kepada seorang anak, akan memberikan pengaruh yang berbeda-beda terhadap pembentukan sosial seorang anak. Dengan demikian pola asuh orangtua sangat penting karena dapat mempengaruhi sikap orangtua terhadap seorang anak secara berkesinambungan (Kohn dalam Krisnawaty, 2010).

Pola asuh yang dilakukan orangtua, terdapat dalam sebuah keluarga. Keluarga yang dimaksud dalam penelitian ini yaitu merupakan sebuah keluarga pemulung. Keluarga pemulung adalah beberapa orang yang memilih memulung dan mencari nafkah dengan cara memungut, serta memanfaatkan beberapa sampah seperti: bungkus rokok, plastic, kertas, kardus bekas dan sebagainya, guna untuk mencukupi kehidupan mereka sehari-hari (Lukman, 2000). 
Bila dilihat secara sepintas, keluarga pemulung dapat ditandai dengan kelusuhan wajah, dan pakaian yang kurang layak untuk dipakai dalam kehidupan sehari-hari (Amalia, 2009).Biasanya dalam menjalankan kehidupan, keluarga pemulung hanya memakai pakaian yang amat sangat sederhana, dan terkadang, pakaian mereka sudah ada yang berlubang, keluarga pemulung hanya memiliki atau mempunyai beberapa pakaian saja yang sering mereka pergunakan dalam kehidupan sehari-hari, pakaian mereka, biasanya berasal dari barangbarang selama mereka bekerja atau mencari nafkah.

Keluarga pemulung merupakansekelompok manusia yang mengalami kekurangan dalam sumber daya sehinggakemampuan social ekonomi keluarga pemulung dalam membiayai pendidikan anak-anaknya sangatlahrendah.Hal ini mengakibatkan beberapa anak dari keluarga pemulung tidak dapatbersekolah. Hidup menjadi pemulung memang bukanlah pilihanyang menyenangkan karena mereka berada dalam kondisi yang tidak memiliki masa depan yang cerah, terkadang keberadaan merekasering menjadi masalah di lingkungan sekitartempat tinggal mereka (Amalia, 2009).

Menurut Sinaga dalam Budi (2013), faktor yang menentukan menjadi keluarga pemulung antara lain, tingkat pendidikan yang rendah dan keterampilan yang terbatas. Kemampuan keluarga pemulung dalam menjalankan peran sosia dapat terlihat dari beberapa aspek yaitu:

(1) dilihat dari kegiatan utama orangtua dalam mencari nafkah, (2) peran orangtua keluarga pemulung dalam mengasuh perilaku sosial anak, (3) peran orangtua keluarga dalam melindungi keselamatan seorang anak

Dalam bekerja atau mencari nafkah keluarga pemulung hanya melakukan kegiatan seperti memungut, mengambil, dan mencari sampah. Sampah yang mereka hasilkandikumpulkan terlebih dahulu kemudian ditukarkan sebagai pendapatan yang mereka dapatkan selama mereka bekerja atau mencari nafkah (Sinaga dalam Budi, 2013).

Dalam mengasuh perilaku sosial seorang anak dan melindungi keselamatan seorang anak, orangtua dari keluarga pemulung hanya menjalankan kegiatan seperti: membimbing anak, mengasuh anak, menemani anak mengajarkan anak dalam menjalankan kehidupan sehari-hari. Kegiatan dalam mengasuh dan melindungi seorang anak dari berbagai macam ancaman yang datang, merupakan kesadaran yang tertanam dalam keluarga pemulung, guna untuk menjaga, melindungi, dan mengasuh anak-anak mereka dalam kehidupan sehari-hari.

Perilaku sosial seorang anak berhubungan erat pada perilaku seorang anak, dalam menyesuaikan diri dengan sebuah peraturan yang berada di lingkungan social tempat tinggal mereka. Perilaku sosial diperoleh anak melalui kematangan dan kesempatan belajar dari berbagai stimulus yang diberikan oleh lingkungannya (Lukman, 2010).

Perilaku baik atau buruk yang terjadi pada seorang anak tergantung bagaimana keluarga menerapkan serta memberikan stimulus yang baik dan patut ditiru oleh seorang anak. Menurut Hurlock (2007), menyatakan bahwa perilaku sosial anak usia dini yang berusia $4-5$ tahun, antara lain seperti berikut: (1) dapat bekerja sama, (2) adanya persaingan, (3) adanya kemurahan hati, (4), simpati, (5) empati, (6) ketergantungan, (7) memiliki sikap ramah kepada lingkungannya, dan (8) suka meniru orang lain.

Adapun tujuan dari penelitian ini yaitu untuk mengetahui gambaran pola asuh orangtua dalam membentuk perilaku sosial pada anak di lingkungan keluarga pemulung.

\section{Perilaku Sosial}

Perilaku sosialadalah hasil dari hubungan antara stimulus dan sebuah respons, perilaku sosial dapat dipelajari denganberbaga cara diantaranya dengan cara menghayati kondisi seorang anak pada saat berada di lingkungan tempat tinggalnya, serta dapat menerangkan apa yang terjadi di dalam kehidupan sehari-hari (Skinner dalam Sarwono, 2002).

Menurut Hurlock (2000), terdapat banyak sekali bentuk perilaku sosial yang terjadi pada diri seorang anak yang berusia 4-5 tahun, antara lain sebagai berikut : adanya kerjasama, adanya hasrat untuk bisa 
mendapatkan penerimaan sosial, adanya simpati, empati, ketergantungan kepada orang lain.

Dalam penulisan perilaku sosial, ada juga pejelasan mengenai perilaku anti sosial, perilaku anti sosial adalah perilaku yang tidak sama sekali memiliki hati nurani atau empati serta simpati kepada orang lain. Perilaku anti sosial sering melanggar norma-norma dan ekpentasi sosial tanpa memiliki rasa bersalah dan penyesalan akan sesuatu hal (Hearn, 2004).

Adapun beberapa ciri-ciri dari perilaku anti sosial antara lain seperti berikut: (1) perkembangan moral para anak anti sosial sering terlambat, (2) para anak anti sosial sering tidak mencontoh perbuatan yang dapat diterima oleh masyarakat, (3) kurang bisa bergaul atau bersosialisasi dengan baik dengan lingkungan.

Jadi yang dimaksud dengan perilaku sosial adalah upaya seseorang untuk mengatur segala aktivitas dirinya sendiri dan untuk menciptakan aktivitas terhadap lingkungan sosialnya dengan amat sangat baik dalam menjalankan kehidupan sehari-hari. sedangkan yang dimaksud dengan perilaku anti sosial adalah perilaku pada diri seseorang yang menggambarkan tidak adanya perilaku empati dan simpati terhadap orang lain di kehidupan ini.

\section{Anak Usia Dini}

Anak usia dini adalah seorang anak yang berbeda dan memiliki karakteristik tersendiri sesuai dengan tahapan usianya, anak usia dini merupakan seorang anak yang berusia (0-6 tahun), yang merupakan masa keemasan atau sering disebut dengan masa Golden Age (Nuryanti, 2010).

Pada dasarnya seorang anak yang masih berusia 4-5 tahun, sudah bisa bersekolah karena pada dasarnya saat ini seorang anak sedang mengalami sebuah masa transis dari kebiasaannya yang diasuh dirumah beranjak kepada seorang anak yang bisa belajar mandiri di lingkungan tempat belajar dan bermainnya. Ketika seorang anak dibiasakan untuk bisa mandiri maka anak akan membutuhkan rasa aman kepada lingkungan dan teman-temannya.

Dalam pembahasan mengenai anak usia dini terdapat pula beberapa perkembangan yang terjadi di dalam kehidupan seorang anak antara lain sebagai berikut: (1) perkembangan kognitif, (2) perkembangan motorik, (3) perkembangan sosial emosional.

Selain itu terdapat pula beberapa macam tingkat pencapaian perkembangan sosio emosional anak usia 4-5 Tahun antara lain sebagai berikut : (1) Menunjukan sikap mandiri dalam memilih kegiatan, (2) menunjukan sikap menolong antara sesama, (3) mampu mengendalikan perasaan, (4) mampu menghormati orang lain, (5) bisa percaya diri, (6) mampu menghargai orang lain di lingkungan sekitar tempat tinggalnya.

\section{METODE PENELITIAN}

Metode penelitian yang digunakan dalam penelitian ini adalah metode kualitatif. Metode penelitian kualitatif adalah penelitian yang digunakan untuk meneliti objek alamiah, dimana peneliti merupakan instrument kunci dalam penulisan penelitian ini (Sugiono, 2005).Penelitian kualitatif adalah metode yang berlandaskan pada filsafat positif, penelitian ini digunakan untuk meneliti objek alamiah dan untuk mengambil sebuah sample sumber data yang berada di lapangan (Sugiono, 2005).

Menurut Sujana dalam Meleong (2005), terdapat beberapa karakteristik penelitiann kualitatif antara lain seperti berikut: (a) penelitian kualitatif menggunakan pola berfikir induktif, (b) penelitian kualitatif sangat menghargai partisipasi responden yang berada di tempat penelitian, (c) penelitian kualitatif memiliki tujuan untuk memahami, mengerti, mencari data, serta menemukan sebuah kebenaran dalam melakukan penelitian kualitatif, (d) adanya beberapa subjek yang menjadi subjek penelitian, (e) pengumpulan data didasarkan atas prinsip fenomologi, serta analisa data dilakukan selama penelitian sedang berlangsung.

\section{HASIL DAN PEMBAHASAN}

Lingkungan kompleks keluarga pemulung ini, setiap harinya dikelilingi oleh beberapa kantung sampah. Kantung sampah tersebut memiliki jumlah yang tidak dapat terhitung jumlahnya, sampah yang didapatkan dan dikumpulkan oleh orangtua keluarga pemulung 
tersebut didapatkan selama mereka bekerja atau mencari nafkah. Berbagai jenis sampah yang orangtua keluarga pemulung dapatkan, antara lain seperti: kertas, kardus, plastik, botol, benang, logam, kapas ,tisu, dan masih banyak lainnya. Berbagai macam sampah yang telah didapatkan, kemudian mereka satukan dan taruh di sebuah kantung yang berguna untuk membawa berbagai macam sampah tersebut. Kemudian mereka memilih dan memilah beberapa jenis sampah yang masih bermanfaat untuk dipergunakan di kehidupan sehari-hari.

Untuk memenuhi kebutuhan hidup sehari-hari dalam melakukan pekerjaan, para orangtua dari keluarga pemulung tersebut tidak diberikan upah kerja seperti system harian atau bulanan. Mereka mendapatkan upah hanya dari barang bekas yang mereka dapatkan atau mereka kumpulkan. Sehingga sarana dan prasarana yang mereka gunakan sangatlah sederhana, hanya seperti karung plastik dan sebuah gancu yang berguna untuk mengukit sampah atau barang bekas yang mereka dapatkkan tersebut (Argo, 2000).

Keluarga pemulung juga menginginkan kehidupan yang baik dan sejahtera, karena dengan kehidupan yang sejahtera tersebut dapat menghindari keluarga pemulung dari keinginan untuk berbuat jahat, seperti mencuri dan merampok. Keberadaan keluarga pemulung tentu menimbulkan banyak asumsi dari berbagai masyarakat, seperti: keluarga pemulung sangatlah kotor dan kumuh, serta keluarga pemulung sangatlah panjang tangan, karena pemulung sebagian besar berasal dari masyarakat golongan bawah. Namun apabila dicermati keluarga pemulung merupakan komponen dalam masyarakat yang mempunyai peranan besar untuk masalah penyelamatan kebersihan lingkungan sosial (Argo, 2000).

Mereka bekerja dengan memungut, mengumpulkan, memilih dan memilah beberapa sampah sehingga pada akhirnya beberapa barang yang berasal dari sampah tersebut dapat dikumpulkan, dibersihkan dan kemudian dapat diolah atau di daur ulang sehingga barang barang tersebut dapat dimanfaatkan kembali dalam kehidupan seharihari (Argo, 2000).
Selain penjelasan di atas, maka peneliti ingin memberikan penjelasan mengenai deskripsi gambaran kompleks pemukiman keluarga pemulung tersebut. Kompleks pemukiman keluarga pemulung ini terdiri dari 2 lantai dan dari 2 lantai tersebut peneliti dapat menyebutkan bahwa terdapat beberapa ruangan kecil yang dipergunakan dan bermanfaat untuk melakukan kehidupan mereka sehari-hari.

Beberapa ruangan yang berada di kompleks pemukiman kumuh keluarga pemulung ini, antara lain sebagai berikut: adanya 18 kamar kecil, adanya dapur, adanya tempat untuk mencuci dan menjemur pakaian, serta adanya sebuah lorong yang dipergunakan untuk berinteraksi serta berdiskusi di setiap harinya. Jumlah keluarga pemulung yang tinggal di lingkungan kompleks keluarga pemulung tersebut berjumlah 25 keluarga, diantaranya merupakan pasangan muda yang sudah menikah dan memiliki seorang anak berusia 4 sampai 5 tahun. Sedangkan jumlah anak yang berada di kompleks pemukiman keluarga pemulung tersebut ada 5 orang anak, namun yang menjadi subjek penelitian hanya 3 orang anak yang berasal dari keluarga pemulung tersebut.

Berdasarkan hasil penelitian yang dilakukan dengan cara observasi, wawancara, serta dokumentasi, maka terdapat beberapa nama subjek penelitian yang berada dan tinggal di lingkungan kompleks keluarga pemulung tersebut, yaitu seperti: (1) KA, (2) AT, (3) AKS. Menurut Hurlock (2000), terdapat banyak sekali bentuk perilaku sosial yang terjadi pada diri seorang anak yang berusia 4-5 tahun, antara lain sebagai berikut: adanya kerjasama, adanya hasrat untuk bisa mendapatkan penerimaan sosial, adanyasimpati, empati, ketergantungan kepada orang lain.

Perilaku social yang tampak pada indikator menghormati orang lain menunjukkan KA selalu berusaha menghormati orang tuanya, AT selalu berusaha menghormati orang tuanya, AKS selalu berusaha menyapa orang lain terlebih dahulu. Hal ini memperlihatkan bahwa pola asuh yang berbeda pada anak menunjukkan perilaku social yang berbeda pula meskipun masing-masing anak belajar untuk selalu menghormati orang lain. Sedangkan pada indikator tolong menolong, KA selalu 
menolong orang lain, orang tua AT sangat jarang menerapkan tolong menolong, dan AKS tidak menunjukkan sikap tolong menolong. Hal ini menunjukkan pentingnya peran orang tuapadasikap anak dalam sikap tolong menolong. Apabila sikap tolong menolong tidak dilatih sedini mungkin, maka anak tidak akan peduli dengan lingkungan sekitarnya.

Pada indikator menjaga sopan santun antara sesama, KA selalu ucapkan salam pada orang lain, AT ketika memanggil temannya harus menggunakan kalimat yang baik, AKS Selalu berusaha sopan ke orangtua. Pada sikap sosial ini, anak menunjukkan sikap sopan santun kepada orang tua, teman, danpada orang lain. Indikator adanya kepedulian dan kepekaan, KA telah memiliki rasa empati dan simpati kepada teman, AT peduli dan peka pada peraturan yang dibuat oleh orang tua, AKS belum menunjukkan kepedualian dan kepekaan kepada lingkungan sekitar.

Pola asuh yang diterapkan dari ke-3 subjek tersebut, yakni KA menggunakan bentuk pola asuh demokratis, AT menggunakan pola asuh otoiter, dan AK menggunakan pola asuh permisive neglectfull. Menurut Kohn dalam Thohah (2002), pola asuh merupakan sikap orangtuadalam berhubungan dengan seorang anak, sikap ini dapat terlihat dari berbagai segi antara lain dari cara orangtua memberikan peraturan kepada seorang anak, cara orangtua memberikan perhatian serta hukuman selama menjalankan kehidupan sehari-hari Pada keluarga pemulung yang melakukan pola asuh otoriter menggunakan pembatasan waktu kepada anak-anak mereka. Tujuannya agar anak-anak mereka tidak merasakan kelelahan ketika sedang menjalankan rutinitas aktivitas di kehidupan sehari-hari dan anak-anak mereka mampu mempergunakan waktu dengan sebaik mungkin.

Masing-masing bentuk pola asuh yang diterapkan akan menghasilkan beberapa dampak yang berbeda-beda untuk ke-3 subjek anak pemulung tersebut. Pada kenyataannya ada yang bersikap mandiri, pemalu, manja, serta jahil ketika mereka sedang menjalankan kehidupan sehari-hari mereka tersebut. Pola asuh yang dilakukan orang tua akan membentuk perilaku sosial anak sehingga perilaku tersebut dapat diterima di lingkungan sosial.

\section{SIMPULAN DAN SARAN}

Adapun hasil dari kesimpulan dari penelitian mengenai gambaran pola asuh orangtua bagi pembentukan perilaku social anak usia dini di keluarga pemulung, antara lain seperti berikut: Pola asuh yang diterapkan oleh orangtua keluarga pemulung dalam kehidupan sehari-hari rata-rata menggunakan bentuk pola asuh demokratis dan pola asuh otoriter.

Pola asuh demokratis adalah pola asuh yang memperioritaskan kepentingan seorang anak, dalam kehidupan sehari-hari. Sehingga anak bisa menjadi mandiri, dan mampu berteman dengan temanya dengan sangat baik. Sedangkan pola asuh otoriter adalah pola asuh yang membatasi dan suka menuntut seorang anak, serta suka menghukum seorang anak, agar dapat menjalankan perintah yang berasal dari orangtua anak tersebut. Sehingga anak yang mendapatkan pola asuh otoriter akan menghasilkan anak yang lemah, ragu-ragu, dan tidak sanggup mengambil sebuah keputusan dengan baik.

Adapun saran yang diberikan untuk orangtua: (1) Sebaiknya orangtua memperhatikan hukuman berdasarkan perbuatan atau perilaku yang dilakukan oleh seorang anak, (2) Sebaiknya orangtua memiliki kelekatan pada seorang anak, selama masa dalam tahap perkembangan tumbuh kembang seoranganak.Saran untuk anak: sebaiknya seorang anak dibiasakan untuk mematuhi peraturan yang dibuat dan diberikan oleh orangtuanya tersebut.

\section{DAFTAR PUSTAKA}

Amalia. (2009). Hubungan antara pendidikan \& perilaku hidup sehat dalam keluarga pemulung.

Baumrind. (2004). Pola asuh orangtua. Jakarta

Baumrind. (2014). Pola asuh orangtua kepada anak usia dini. Jakarta: Balai Cipta.

B.H.E. (2000). Psikologi perkembangan. PT. Gelora Aksara Pratama

B.H.E. (2005). Psikologi perkembangan anak. Jakarta.

Hurlock, E. (2010). Perkembangan anak usia dini. Jakarta.

Budi, A.E.S. (2013). Kendala-kendala yang dihadapi masyarakat miskin dalam mengakses pendidikan \& pola asuh pada 
keluarga pemulung di Kelurahan Gunung Gullah.

Hurlock, E.B. (2010). Psikologi perkembangan suatu pendidikan sepanjang rentang kehidupan. Jakarta: Erlangga.

Ansrenaz, M., Hearns, A.J., Ross, J. (2004). Pembelajaran perilaku sosial anak usia dini.

Twikrno, Argo. (2000). Kehidupan pemulung jalanan daerah Yogyakarta (Cet: 1, Yogyakarta: Media Presindo, 2000, halaman 275-260).

Lukman, M. (2000). Evaluasi pendidikan dan seminar pendidikan nasional. Lembaga Ilmu Pendidikan. Bogor.

Krisnawaty. (2010). Pola asuh orangtua. Artikel Pola Asuh Terhadap Anak Usia Dini.

Lukman, A-F. (2000). Upaya pengembangan pendidikan karakter di sekolah dasar negeri. Skripsi, Yogyakarta FKIP PGSD. UNY Yogyakarta.
Mahmud. (2003). Metode Penelitian Pendidikan \& Pola Asuh. Bandung: CV Pustaka Setia.

Meleong L. (2005). Metode Penelitian Kualitatif. Bandung: PT. Remaja Rosdakarya.

Meleong, L. (2009). Metode Penelitian Kualitatif. Bandung: PT. Remaja Rosdakarya.

Nuryanti, L. (2010). Psikologi anak usia dini.

Thoha, M. (2002). Organisasi konsep dasar \& aplikasi pola asuh. PT. Raja Grafindo Persada. Jakarta

Sarwono. (2002). Teori psikologi sosial. Jakarta: PT. Raja Grafindo Persada.

Sugiono. (2005). Metode penelitian kualitatif dan penelitian kuantitatif, serta riset $R \& D$. Bandung: PT. Alfabeta.

Wardoesoejono. (2002). Pendidikan perilaku sosial dalam keluarga pemulung. Jakarta 